\title{
Cloning and Characterization of $R 3 b$; Members of the R3 Superfamily of Late Blight Resistance Genes Show Sequence and Functional Divergence
}

\author{
Guangcun Li, ${ }^{1,2}$ Sanwen Huang, ${ }^{2,3}$ Xiao Guo, ${ }^{1}$ Ying Li, ${ }^{3}$ Yu Yang, ${ }^{1}$ Zhen Guo, ${ }^{1}$ Hanhui Kuang, ${ }^{4}$ \\ Hendrik Rietman, ${ }^{2}$ Marjan Bergervoet, ${ }^{2}$ Vivianne G. G. A. Vleeshouwers, ${ }^{2}$ Edwin A. G. van der Vossen, ${ }^{2}$ \\ Dongyu Qu, ${ }^{3}$ Richard G. F. Visser, ${ }^{2}$ Evert Jacobsen, ${ }^{2}$ and Jack H. Vossen ${ }^{2}$
}

${ }^{1}$ Key Laboratory of Crop Genetic Improvement and Biotechnology, Shandong Province, Shandong Academy of Agricultural Sciences, Jinan 250100, P. R. China; ${ }^{2}$ Wageningen UR Plant Breeding, P.O. Box 16, 6700AA, Wageningen, The Netherlands; ${ }^{3}$ Key Laboratory of Horticultural Crops Genetic Improvement of Ministry of Agriculture, Sino-Dutch Joint Lab of Horticultural Genomics Technology, Institute of Vegetables and Flowers, Chinese Academy of Agricultural Sciences, Beijing 100081; ${ }^{4}$ Key Laboratory of Horticulture Biology, Ministry of Education, and Department of Vegetable Crops, College of Horticulture and Forestry, Huazhong Agriculture University, Wuhan, 430070, P.R. China

Submitted 30 November 2010. Accepted 26 May 2011.

\begin{abstract}
Massive resistance $(R)$ gene stacking is considered to be one of the most promising approaches to provide durable resistance to potato late blight for both conventional and genetically modified breeding strategies. The $R 3$ complex locus on chromosome $\mathrm{XI}$ in potato is an example of natural $R$ gene stacking, because it contains two closely linked $R$ genes $(R 3 a$ and $R 3 b)$ with distinct resistance specificities to Phytophthora infestans. Here, we report about the positional cloning of $R 3 b$. Both transient and stable transformations of susceptible tobacco and potato plants showed that $R 3 b$ conferred full resistance to incompatible $P$. infestans isolates. $R 3 b$ encodes a coiled-coil nucleotidebinding site leucine-rich repeat protein and exhibits $82 \%$ nucleotide identity with $R 3 a$ located in the same $R 3$ cluster. The $R 3 b$ gene specifically recognizes $A v r 3 b$, a newly identified avirulence factor from $P$. infestans. $R 3 b$ does not recognize Avr3a, the corresponding avirulence gene for $R 3 a$, showing that, despite their high sequence similarity, $R 3 b$ and $R 3 a$ have clearly distinct recognition specificities. In addition to the Rpi-mcd1/Rpi-blb3 locus on chromosome IV, the $R 3$ locus on chromosome XI is the second example of an $\boldsymbol{R}$-gene cluster with multiple genes recognizing different races of $P$. infestans.
\end{abstract}

Potato (Solanum tuberosum L.) is the most important noncereal crop plant and ranks in fourth place in world food production (Reader 2009). This crop is continually threatened by a dozens of pathogens and pests that result in billions of U.S. dollar losses annually. Late bight, caused by the oomycete Phytophthora infestans, still remains the most important pathogen in potato-producing regions of the world, causing approximately $\$ 6.7$ billion losses annually (Haverkort et al. 2008). Management of this devastating pathogen is challenged by its remarkable speed of adaptation to control strategies such as genetically resistant cultivars by using major resistance $(R)$ genes (Fry 2008; McDonald and Linde 2002).

G. Li and S. Huang contributed equally to this work.

Corresponding author: J. Vossen; E-mail: jack.vossen@wur.nl
Disease management is currently based on the application of fungicides but it imposes high input costs and results in air, water, and soil pollution. In spite of the application of high amounts of chemicals, late blight is increasingly more difficult to control. Introduction of resistance genes from wild Solanum spp. into potato cultivars is considered to be the most promising and environment-safe approach to achieve late blight resistance. However, introgressed resistances that are based on single $R$ genes have proven to be not durable. Therefore, an $R$-gene stacking approach is postulated to be required for durability (Jacobsen and Hutten 2006). This can be achieved through marker-assisted breeding or trans- or cisgenic strategies (Jacobsen and Schouten 2007). The first approach requires accurate mapping positions and robust molecular markers. This can be achieved by cloning the genes responsible for resistance, which is a prerequisite for the second approach, trans- or cisgenesis. Therefore, efforts from several laboratories worldwide focus on the identification of resistance sources and mapping of the corresponding traits. From the wild species $S$. demissum alone, 11 pathogen race-specific resistance classes have been identified. Several of them were mapped on the short arm of chromosome 11 (Bradshaw et al. 2006; El Kharbotly et al. 1994, 1996), including the $R 3$ locus (Huang et al. 2004).

The $R 3$ locus of potato ( $S$. tuberosum L.) confers full resistance to avirulent isolates of $P$. infestans. $R 3$ resides on the short arm of chromosome 11 and segregates in the diploid SH83-92$488(\mathrm{SH}) \times \mathrm{RH} 89-039-16(\mathrm{RH})$ population, which was used to construct the ultra-high-density (UHD) amplified fragment length polymorphism (AFLP) potato map (Huang et al. 2004; Isidore et al. 2003; van Os et al. 2006). The $R 3$ locus is composed of two functional genes, $R 3 a$ and $R 3 b$, which are 0.4 centimorgans (cM) apart. A recombination event between the two genes allowed their separation, and successive characterization of recombinant plants showed that the two genes have different pathogen isolate-recognition specificities (Huang et al. 2004). Isolate race specificity is a phenomenon common to host-specific resistance and is explained by an arms race that has taken place during co-evolution (Boller and He 2009; Dangl and Jones 2001; Parker and Gilbert 2004). The $R$-gene product directly or indirectly recognizes a pathogen component which is referred to as an effector. This recognition results in an incompatible inter- 
action on plants harboring the resistance gene and, therefore, the cognate effector is also referred to as an avirulence (Avr) gene. The effector recognized by the $R 3 a$ gene has been identified and is referred to as Avr3a (Armstrong et al. 2005). The $R 3 a$ gene has been isolated via a combination of map-based cloning strategy and resistance gene analog approach (Huang et al. 2005a). It encodes a putative coiled-coil nucleotide-binding site leucinerich repeat (CC-NBS-LRR) protein and shares $88 \%$ nucleotide identity and $83 \%$ amino acid similarity with $I-2$, a tomato gene conferring resistance to the soilborne fungus Fusarium oxysporum (Simons et al. 1998).

In this study, a map-based cloning strategy was used to clone the $R 3 b$ gene, a paralog of $R 3 a$. We also found that $A v r 3 b$ was specifically recognized by $R 3 b$ and not by $R 3 a$. Both isolate spectrum and effector recognition showed that $R 3 a$ and $R 3 b$
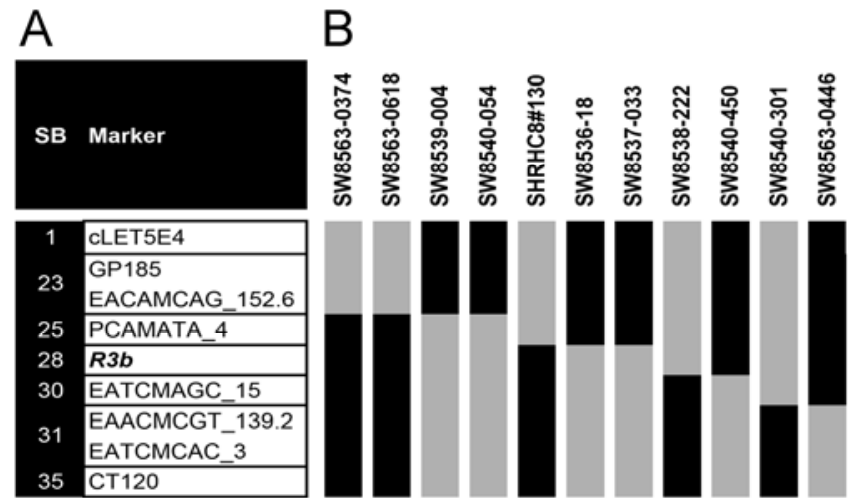

Fig. 1. High-resolution genetic map of $R 3 b$. A, High-resolution map of $R 3 b$. The sub-bins (SB) are numbered from 1 to 35 in a proximal-distal order. On the right, markers are assigned to sub-bins. B, Graphical genotypes of $11 \mathrm{SH} 83-92-488 \times \mathrm{RH} 89-039-16(\mathrm{SH} \times \mathrm{RH})$ progeny that carry cross-over in the $R 3 b$ region. Black and gray indicate the presence and absence, respectively, of the marker allele in cis to $R 3 b$. The transition of black and gray indicates a cross-over. have clearly distinct recognition specificities. Therefore, $R 3 b$ is a new candidate for $R$-gene stacking approaches and the cloning of the gene provides tools for its introduction into new cultivars.

\section{RESULTS}

High-resolution genetic mapping of the $R 3 b$ locus.

In the potato UHD map produced by van Os and associates (2006), the $R 3$ locus was mapped within the Bins SH11B65 to $\mathrm{SH} 11 \mathrm{~B} 67$ between two cleaved amplified polymorphic sequence (CAPS) markers, cLET5E4 and CT120 (Huang et al. 2004) (Fig. 1). From $1,748 \mathrm{SH} \times \mathrm{RH}$ progeny, 34 recombinants in the cLET5E4-CT120 interval were found. These recombinants divided the interval into 35 sub-bins (SB), each equivalent to $0.05 \mathrm{cM}$. Detached leaf assays (DLA) on these recombinants revealed that $R 3 b$ resides in SB28 (Fig. 1). The closest flanking markers were EACAMCAG_152.6 (SB23), GP185 (SB23), and PCAMATA_4 (SB25) at the proximal side and EATCMAGC_15 (SB30), EAACMCGT_139.2 (SB31), and EATCMCAC_3 (SB31) at the distal side. Of the 34 recombinants, 8 had recombinations at the SB23 to SB31 interval. Later, an additional 1,200 $\mathrm{SH} \times \mathrm{RH}$ progeny were screened using cLET5E4 and CT120 for more recombinants in the $R 3 b$ region and three new recombinants were identified at the SB23 to SB31 interval. Consequently, a genetic map of $R 3 b$ with a resolution of $0.03 \mathrm{cM}$ was successfully constructed (Fig. 1).

\section{Physical mapping of the $R 3 \boldsymbol{b}$ locus.}

For the physical mapping of $R 3 b$, two bacterial artificial chromosome (BAC) libraries of the resistant parent SH were constructed with two different restriction enzymes, HindIII and EcoRI, which were equivalent to a 10- and 33-fold coverage, respectively, of the potato haploid genome. First, the HindIII BAC library was screened with the AFLP and CAPS markers in SB23, 25, 30, and 31 (Figs. 1 and 2). Only two BAC clones, SH96A7 (which carries the GP185 allele in cis to

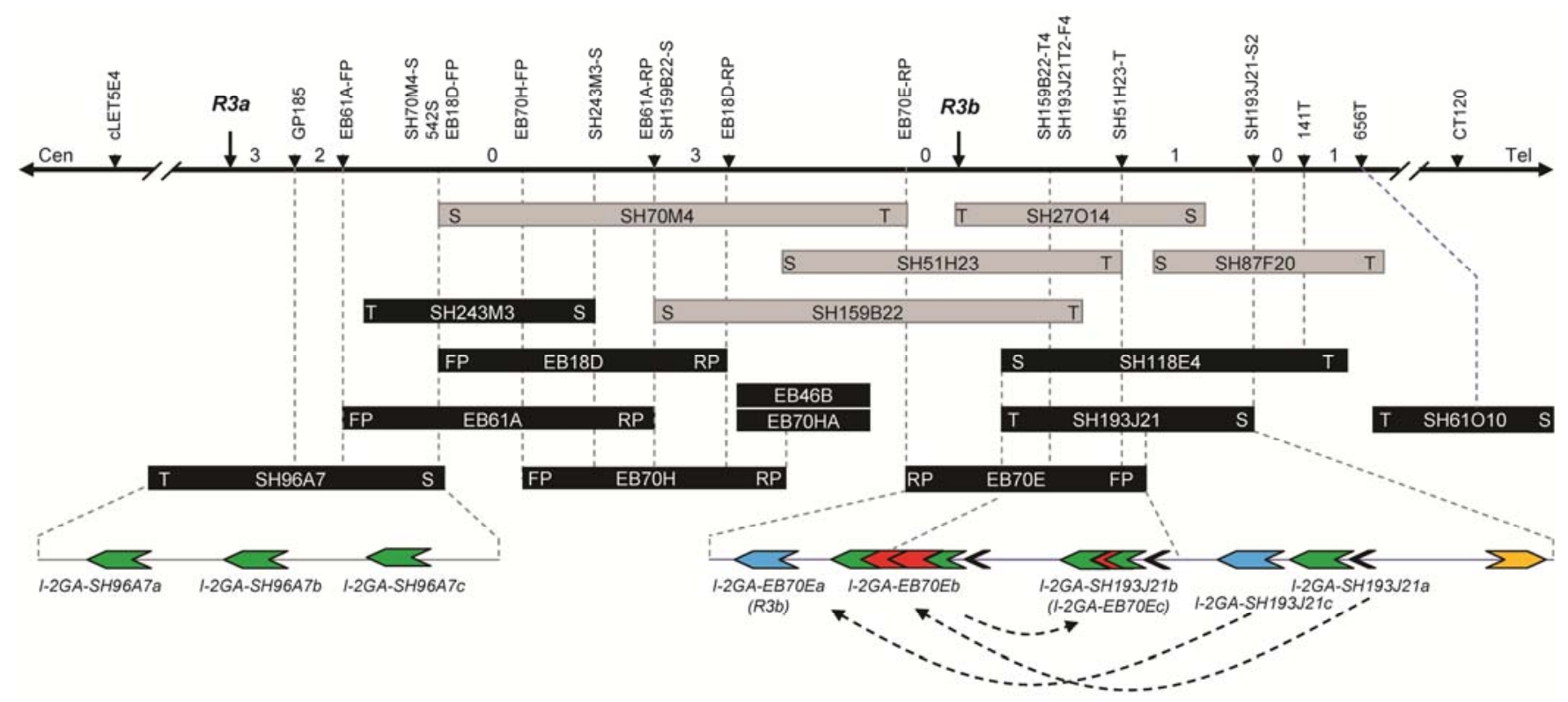

Fig. 2. Combined physical and genetic maps of the $R 3 b$ region in both SH83-92-488 (SH) haplotypes. Vertical arrows indicate the genetic positions of markers, disease resistance, and figures in between markers indicate the number of recombinants in between the markers. Gray, hatched lines indicate physical positions of markers in the contig. Gray and black rectangles represent bacterial artificial chromosomes (BAC) in trans and in cis to R3b, respectively. T (T7) and S (Sp6) indicate the orientation of BAC derived from the HindIII BAC library, while FP and RP indicate the orientation of BAC derived from the EcoRI BAC library. Green and blue boxed arrows indicate the location and orientation of $I-2$ gene analogs (GA). Red boxed arrows show the position of retrotransposon sequences. Black arrowheads show the position of short coding sequences upstream of $I-2 \mathrm{GA}$. Yellow boxed arrow shows the position of a putative transposase associated with mutator elements. Hatched arrows indicate the suggested sequential duplications of I-2GA. 
$R 3 b$ ) and SH61O10 (which carries the EATCMAGC_15 allele in $c i s$ to $R 3 b$ ), were identified. Unfortunately, BAC ends of SH96A7 could not be developed into polymerase chain reaction (PCR) markers. Also, no new BAC was identified using marker SH61O10-T. Therefore, the gap between BAC SH96A7 and SH61O10 could not readily be bridged.

In a previous study, a contig of six BAC (PGEC152I15, PGEC417F14, PGEC481F15, PGEC409I1, PGEC563P22, and PGEC400L14), hereafter referred to as the PGEC152I15400L14 contig, in the $R 7$ region was determined to span the $R 3 b$ region in one of the haplotypes in plant introduction (PI) 161729 of S. demissum (Dr. Barbara Baker, University of California Berkeley, personal communication). This contig was fully sequenced, spanning a physical distance of $488 \mathrm{~kb}$. To bridge the SH96A7-SH61O10 gap in our SH-BAC library, several markers (Table 1) were developed from the PGEC152I15$400 \mathrm{~L} 14$ contig and mapped in the $R 3 b$ high-resolution genetic map. Successively, several BAC clones from the SH BAC library were identified using these new PGEC152I15-400L14 markers. Two BAC (SH243M3 and SH118E4) are linked in cis to $R 3 b$. SH118E4 end markers were developed and showed that the SH96A7-SH61O10 gap was narrowed but still not closed. Five other overlapping BAC clones (SH70M4, SH159B22, SH51H23, SH27O14, and SH87F20) were determined to be in trans to $R 3 b$ (Fig. 2) and constituted a new BAC contig referred to as the $r 3 b$ region. Sequence analysis of BAC SH159B22 and SH27O14 revealed the presence of an $I-2$ gene analog (GA) cluster (referred to as the SL8 cluster) in the $r 3 b$ region. The SL8 cluster consisted of multiple transposable elements, five complete $I-2 \mathrm{GA}$, and five partial pseudogenes with homology to I-2 (Table 2). Although the SH118E4$\mathrm{SH} 243 \mathrm{M} 3$ gap remained in the $R 3 b$ region, sequence information from the trans phase was used to produce new cis phase markers. Despite many efforts, only one cis-phase marker could be developed, showing an apparent lack of synteny between the $r 3 b$ and $R 3 b$ region. CAPS marker $\mathrm{SH} 51 \mathrm{H} 23-\mathrm{T}$ was cosegregating in cis with $R 3 b$.

SL8 primers (Table 1) and the cis phase marker SH51H23-T were used to screen the SH library and a new BAC, SH193J21, was identified. SH193J21 largely overlapped with BAC SH118E4 and yielded no new sequence information for marker development. Therefore, BAC SH193J21 and SH159B22 were sequenced, and several sequence-characterized amplified region (SCAR) markers (SH193J21-T4, SH159B22-S, and SH159B22$\mathrm{T} 4)$ in $c i s$ to $R 3 b$ were developed. In addition, SH159B22-T4 and SH193J21-T4 cosegregated with $R 3 b$. Unfortunately, no new BAC clones in this region were identified using these three new SCAR markers in the HindIII BAC library. A new

Table 1. Overview of markers used for mapping $R 3 b^{\mathrm{a}}$

\begin{tabular}{|c|c|c|c|c|}
\hline Marker & Orientation of the primer & Sequence $\left(5^{\prime}-3^{\prime}\right)$ & Annealing temperature $\left({ }^{\circ} \mathrm{C}\right)$ & Restriction enzyme \\
\hline \multirow[t]{2}{*}{ cLET5E4 } & $\mathrm{F}$ & CCAGGCATGCTCAATTTGGAGT & 55 & HhaI \\
\hline & $\mathrm{R}$ & TTCCCTGTTTGGACTACTTGTGGA & & $\ldots$ \\
\hline \multirow[t]{2}{*}{ CT120 } & $\mathrm{F}$ & CGAGGGGGCGAAGGATT & 52 & Tsp509I \\
\hline & $\mathrm{R}$ & CCATGAGATAAACGAGGAACCAGT & & $\ldots$ \\
\hline \multirow[t]{2}{*}{ SL8D } & $\mathrm{F}$ & AATTGGAGAGTTCCCTACACTTGAG & 50 & AluI \\
\hline & $\mathrm{R}$ & AGGGAGGAGGGCAGTGCTGATTC & & $\ldots$ \\
\hline \multirow[t]{2}{*}{ SL8E } & $\mathrm{F}$ & GAATGTTCTCTTTGATAGGCTTGCTC & 50 & $\ldots$ \\
\hline & $\mathrm{R}$ & GGGCAATCCTCCTTCAGGAAADGA & $\ldots$ & $\ldots$ \\
\hline \multirow[t]{2}{*}{ GP185 } & $\mathrm{F}$ & CTGGTAATAGTAGTAATGATTCTTCGTC & 54 & Bst $\mathrm{UI}$ \\
\hline & $\mathrm{R}$ & TTGTTCAATGGAGCACTTGC & & $\ldots$ \\
\hline \multirow{2}{*}{$542 \mathrm{~S}$} & $\mathrm{~F}$ & GTCTGCCCGTATACCCCTCTTC & 52 & ApoI/MseI \\
\hline & $\mathrm{R}$ & CAGCCGTTGGTGTCTTTGTTCTTG & $\ldots$ & $\ldots$ \\
\hline \multirow[t]{2}{*}{$141 \mathrm{~T}$} & $\mathrm{~F}$ & GATTGATCTAATTGGATGCATTG & $\ldots$ & SspI/HinfI \\
\hline & $\mathrm{R}$ & TTATTCGGTGTCTGATATCGC & $\ldots$ & $\ldots$ \\
\hline \multirow[t]{2}{*}{$656 \mathrm{~T}$} & $\mathrm{~F}$ & CAAGTCATGGAAAATTAACATGG & $\ldots$ & HPYCH41V \\
\hline & $\mathrm{R}$ & AATTGTTCCTTTCTTCAGAATGC & & $\ldots$ \\
\hline \multirow{2}{*}{ SH159B22-S } & $\mathrm{F}$ & CATGCATGTAGGAGGAGGAG & 55 & TaqI \\
\hline & $\mathrm{R}$ & TAGTTGAATGCTCATTCATCTAG & & $\ldots$ \\
\hline \multirow[t]{2}{*}{ SH243M3-S } & $\mathrm{F}$ & GCTGTGATCATCTTGGACTTG & 54 & $\ldots$ \\
\hline & $\mathrm{R}$ & ATATGTTCTTTCTCCTTGTTAGC & . & $\ldots$ \\
\hline \multirow[t]{2}{*}{ SH159B22-T4 } & $\mathrm{F}$ & TTGATGGATCCTTTCCCGC & 55 & SCAR \\
\hline & $\mathrm{R}$ & AATCGTGCGAGCTCACACC & $\ldots$ & $\ldots$ \\
\hline \multirow[t]{2}{*}{ SH51H23-T } & $\mathrm{F}$ & TAAGCTTGTCTTCCCATAAC & 54 & Bst UI \\
\hline & $\mathrm{R}$ & TTCCGTCAATATAAAGAGATC & & $\ldots$ \\
\hline \multirow{2}{*}{ SSH193J21T2-F4 } & $\mathrm{F}$ & GCCCAATCGACATATTATTTCACC & 62 & SCAR \\
\hline & $\mathrm{R}$ & GCTAAATTATTGTTCTTGCAGGTGC & & $\ldots$ \\
\hline \multirow[t]{2}{*}{ SH193J21-S2 } & $\mathrm{F} 2$ & GCATGTTTGCATCGTACTATGG & 60 & SCAR \\
\hline & R2 & GGTCTAGACAAATGTGGTGTGTG & & $\ldots$ \\
\hline \multirow[t]{2}{*}{ EB61A-FP } & $\mathrm{F}$ & GAAGGAAGCTGTCCCAGTGC & 60 & $\ldots$ \\
\hline & $\mathrm{R}$ & GAAGATGCCGCTACGTCTGAG & & \\
\hline \multirow[t]{2}{*}{ EB61A-RP } & $\mathrm{F}$ & CAATCGAATATTTATCGCTGTG & 55 & SCAR \\
\hline & $\mathrm{R}$ & ATGGGTTAAGATTTGATGGG & $\ldots$ & $\ldots$ \\
\hline \multirow{2}{*}{ EB70H-FP } & $\mathrm{F}$ & CAAGGCACCTGCTATCTCC & 54 & SCAR \\
\hline & $\mathrm{R}$ & TTGTCTTGCAGGCATTGAG & $\ldots$ & $\ldots$ \\
\hline \multirow[t]{2}{*}{ EB70H-RP } & $\mathrm{F}$ & GTGGTACTGTTTTATGCATGG & 56 & a.s. \\
\hline & $\mathrm{R}$ & TTCGTCGAGAATTTCTCTGTG & & $\ldots$ \\
\hline \multirow[t]{2}{*}{ EB18D-FP } & $\mathrm{F}$ & GAAACTCGTTGAACTCTGCTTGC & 60 & $\ldots$ \\
\hline & $\mathrm{R}$ & TGTGCCAGAGAATGATGTAGGC & & $\ldots$ \\
\hline \multirow[t]{2}{*}{ EB18D-RP } & $\mathrm{F}$ & AATCTCGAGCTCATGCACG & 55 & SCAR \\
\hline & $\mathrm{R}$ & TTTCTTGCACCCGTCTTCC & & $\ldots$ \\
\hline \multirow[t]{2}{*}{ EB70E-FP } & $\mathrm{F}$ & GACATTGGGCTAAGACCAAAC & 54 & a.s. \\
\hline & $\mathrm{R}$ & GTTTGGTCTTAGCCCAATGTC & & \\
\hline \multirow[t]{2}{*}{ EB70E-RP } & $\mathrm{F}$ & CCATTTTCTTCATTTACTAGTCG & 55 & $A l u \mathrm{I}$ \\
\hline & $\mathrm{R}$ & TATACCCACACAAATGTGTATC & $\ldots$ & $\ldots$ \\
\hline
\end{tabular}

${ }^{\mathrm{a}} \mathrm{F}$, forward primer; R, reverse primer; SCAR, sequence-characterized amplified region; a.s., allele specific. 
BAC library was constructed with restriction enzyme EcoRI and screened with these three different SCAR markers. In this new library, several BAC clones (EB18D, EB61A, EB70H, and $\mathrm{EB} 70 \mathrm{E}$ ) in cis to $R 3 b$ were identified, further narrowing the gap (Fig. 2). Based on BAC end sequences, two markers cosegregating in cis (EB18D-RP and EB70E-RP) were developed by which two new overlapping BAC clones (EB70HA and EB46B) were identified. Unfortunately, also in the EcoRI library, no additional BAC were found that bridged the gap between EB46B and EB70E. To identify I-2 homologs in the identified BAC clones, I-2GA sequences, amplified from SH193J21 using SL8E primers, were used as a probe for Southern blot analysis. I-2GA were detected in SH118E4, SH193J21, SH96A7, and EB70E but not in EB18D, EB70H, and EB46B (data not shown). Because of their co-segregation with $R 3 b$, I-2GA in EB70E and SH193J21 were considered to contain candidate genes for $R 3 b$.

\section{Selection of $R 3 \boldsymbol{b}$ candidate genes.}

BAC clones EB70E and SH193J21 were sequenced. Annotation of EB70E and SH193J21 predicted five I-2GA, designated as I-2GA-EB70Ea, I-2GA-EB70Eb, I-2GA-EB70Ec $=I-$ 2GA-SH193J21b, I-2GA-SH193J21a, and I-2GA-SH193J21c (Fig. 2; Table 2). I-2GA-SH193J21a was considered to be a pseudogene because of the presence of several frameshifts. $I$ $2 G A-E B 70 E b$ and $I-2 G A-S H 193 J 21 b$ contained insertions of retrotransposon sequences; I-2GA-EB70Ea and I-2GA$S H 193 J 21 c$ contained uninterrupted single-exon open reading frames and were considered the most likely $R 3 b$ candidates. $I$ 2GA-EB7OEa and I-2GA-SH193J21c were subcloned into binary vector pBINPLUS (van Engelen et al. 1995) using partial digestion of the original BAC with enzyme Sau3A. The right subclones were selected using specific PCR and restrictionenzyme fingerprinting and were successively transformed into Agrobacterium sp. strains COR308 and AGL0.

Candidates were transiently expressed in Nicotiana benthamiana leaves and successively inoculated in DLA with $P$. infestans isolates 89148-9 (Avr3a and Avr3b) and IPO-0 (Avr3a and $a v r 3 b$ ). Phenotypes were scored at 7 days postinoculation. Only subclone EB70E-76, which contained I-2GA-EB70Ea and its up- and downstream (2,150 and 2,140 bp, respectively) sequences, gave a resistant phenotype on the $N$. benthamiana leaves inoculated with the $R 3 b$-incompatible late blight isolate 89148-9 (data not shown). The leaves expressing the other subclones, including the subclone SH193J21-321 that contained I-2GA-SH193J21c, showed large sporulating lesions after inoculation with $89148-9$. As expected, full susceptibility was observed with all constructs, including EB70E-76, when inoculated with the $R 3 b$-compatible isolate IPO- 0 .

\section{Complementation analysis in stable transgenics.}

The genes I-2GA-EB70Ea and I-2GA-SH193J2Ic, together with 2- to $3-\mathrm{kb}$ up- and downstream sequences, were introduced into susceptible 'Desiree' plants through Agrobacteriummediated transformation. At least 10 in vitro plantlets of each primary transformant were tested for resistance to $P$. infestans isolates 89148-9 and IPO-0 in duplicate experiments. Desiree and $\mathrm{RH}$ were included as susceptible controls, and $\mathrm{SH}$ and SW8563-618 ( $R 3 b$ recombinant) were included as resistant controls. Upon analysis of the primary transformants, only subclone EB70E-76, containing I-2GA-EB70Ea, was able to specifically complement the susceptible phenotype (Fig. 3A), which was consistent with the transient complementation results in $N$. benthamiana described in the previous section. All primary transformants of this subclone exhibited $R 3 b$-specific resistance to isolate 89148-9 and susceptibility to IPO-0 (Fig. $3 \mathrm{~A})$. The results were confirmed using a DLA in duplicate tests (Fig. 3B). Because subclone EB70E-76 contained only one gene, we conclude that $I-2 G A-E B 70 E a$ is the $R 3 b$ gene.

\section{R3b specifically recognizes Avr3b.}

In parallel studies, $A v r$ genes matching specific $R$ genes are being identified by high-throughput effector genomics (Oh et al. 2009; Vleeshouwers et al. 2008). Effector candidates carrying a signal peptide and RXLR motif were mined from the recently sequenced $P$. infestans isolate T30-4 (Haas et al. 2009; Haverkort et al. 2008), which is avirulent to $R 3 b$ plants (Huang et al. 2004). Effectors were expressed through Agrobacterium tumefaciens (Rietman 2011) and co-infiltrated with $R 3 b$ in $N$. benthamiana leaves. One clone, PITG_18215, was specifically recognized by $R 3 b$, as was evident from the induced hypersensitive response (Fig. 4A) (Rietman 2011). $R 3 b$ did not recognize $A v r 3 a$, and neither did $R 3 a$ recognize $A v r 3 b$ (Fig. 4B). These results further functionally confirm the iden-

Table 2. Overview of sequences from different haplotypes in the $R 3 b$ region $^{\mathrm{a}}$

\begin{tabular}{|c|c|c|c|}
\hline Haplotype & BAC (accession number) & Complete I-2GA (position) & Partial $I$-2GA and pseudogenes (position) \\
\hline \multirow[t]{8}{*}{ PI161729-r3b } & PGEC152I5 (AC136471) & $\ldots$ & $\ldots$ \\
\hline & PGEC417F14 (AC149289) & $\ldots$ & $\ldots$ \\
\hline & PGEC481F15 (AC149488) & $S d-481 \mathrm{~F} 15-\mathrm{a}(29270-33214)$ & $S d-481 \mathrm{~F} 15-\mathrm{c}(78315-82084)$ \\
\hline & & $S d-481 \mathrm{~F} 15-\mathrm{b}(41747-45655)$ & $\ldots$ \\
\hline & PGEC409I1 (AC142210) & $\ldots$ & $\ldots$ \\
\hline & PGEC563P22 (AC150163) & $\ldots$ & $S d-563 \mathrm{P} 22-\mathrm{a}(5170-10028)$ \\
\hline & & $\ldots$ & $S d-563 \mathrm{P} 22-\mathrm{b}(13560-16171)$ \\
\hline & PGEC400L14 (AC149302) & $S d-400 \mathrm{~L} 14(13560-16171)$ & $\ldots$ \\
\hline Haplotype & BAC (accession number) & Complete I-2GA (accession number) & Partial $I$-2GA and pseudogenes (accession number) \\
\hline \multirow[t]{2}{*}{$\overline{\mathrm{SH}-r 3 b}$} & SH159B22 & $\begin{array}{l}\text { SH159B22b (EF638450) } \\
\text { SH159B22c (EF638451) }\end{array}$ & SH159B22a (EF638459) \\
\hline & SH27O14 & $\begin{array}{l}\text { SH27O14e (EF638455) } \\
\text { SH27O14f (EF638456) } \\
\text { SH27O14b (EF638454) } \\
\text { SH27O14g (EF638457) }\end{array}$ & $\begin{array}{l}\text { SH27O14a (EF638461) } \\
\text { SH27O14c (EF638462) } \\
\text { SH27O14d (EF638463) }\end{array}$ \\
\hline \multirow[t]{3}{*}{$\mathrm{SH}-\mathrm{R} 3 b$} & SH96A7 & $\begin{array}{l}\text { SH96A7a (EF638458) } \\
\text { SH96A7b (EF638464) }\end{array}$ & SH96A7c (EF638465) \\
\hline & SH193J21 (JF900492) & SH193J21c (EF638453) & $\begin{array}{l}\text { SH193J21a (EF638460) } \\
\text { SH193J21b = EB70Ec (EF638452) }\end{array}$ \\
\hline & EB70E (JF900492) & $\mathrm{EB} 70 \mathrm{Ea}=R 3 b(\mathrm{HQ} 437670)$ & EB70Eb (HQ437669) \\
\hline
\end{tabular}

\footnotetext{
${ }^{\text {a }}$ Bacterial artificial chromosome (BAC) clones and $I-2$ gene analogs (GA).
} 
tity of $R 3 b$. Also, it shows that $R 3 b$ and $R 3 a$ have clearly distinct recognition specificities.

$\boldsymbol{R} 3 \boldsymbol{b}$ gene structure and predicted amino acid sequence.

The $R 3 b$ gene consists of one exon containing a single open reading frame of 3,855 nucleotides. The predicted $R 3 b$ transcript encodes a polypeptide of 1,284 amino acids. The structure of the $R 3 b$ gene is similar to $R 3 a$, encoding a putative CCNBS-LRR protein. $R 3 b$ and $R 3 a$ exhibit $82 \%$ identity at the nucleotide level and $73 \%$ similarity at the amino acid level. The N-terminal half of the $\mathrm{R} 3 \mathrm{~b}$ protein contains three potential $\mathrm{CC}$ domains and seven conserved NB-ARC subdomains (Fig. 5). R3b and $\mathrm{R} 3 \mathrm{a}$ proteins are quite conserved in the $\mathrm{CC}$ domain (79\% amino acid [aa] identity) and NBS domain $(75 \%$ aa identity), especially at the motifs that define the domain $(86 \%$ aa identity). The $\mathrm{C}$ terminus of $\mathrm{R} 3 \mathrm{~b}$, referred to as LRR in Figure 4, shares $67 \%$ aa identity with R3a.
The C-terminal half of R3b comprises a series of 28 irregular LRR that can be aligned according to the consensus sequence $x x L x L x x$ observed in other cytoplasmic $\mathrm{R}$ proteins. Although most of the LRR in R3a and R3b can be aligned to each other, obvious differences were observed between them. The $R 3 a$ gene encodes 29 LRR and the $R 3 b$ gene only 28 (Fig. 5 , line 30 ). In addition, both genes have two unique LRR (Fig. 5 , lines $14 / 15$ and $26 / 27$ ). In the LRR domain, only $45 \%$ $(81 / 182)$ of the putative solvent-exposed residues ( $x$ in the frame xxLxLxx) were conserved between R3a and R3b. This hypervariability fits the hypothesis that the LRR region of $R$ proteins may define recognition specificity. Among the known $P$. infestans $R$ genes, $R 3 b$ shares highest identity with $R 3 a$ and bears limited similarity (50\% identity in nucleotides and $34 \%$ in amino acids) to RB/Rpi-blbl (Song et al. 2003; van der Vossen et al. 2003). All other known late blight R proteinsR1 (Ballvora et al. 2002), Rpi-blb2 (van der Vossen et al.
A Desiree
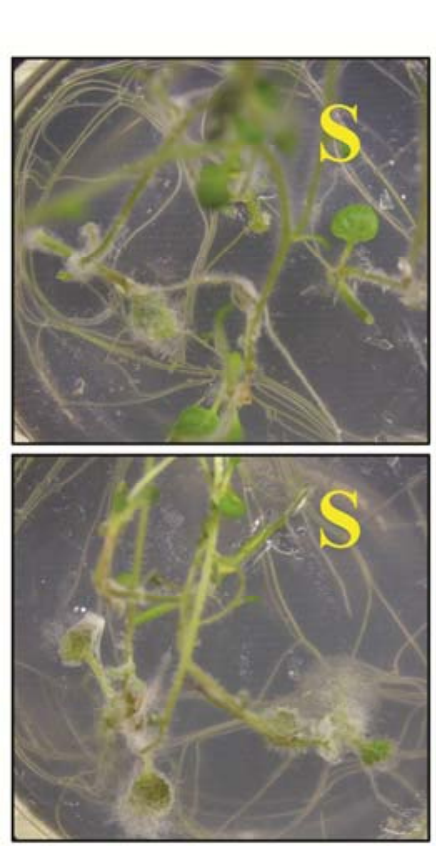

B Desiree

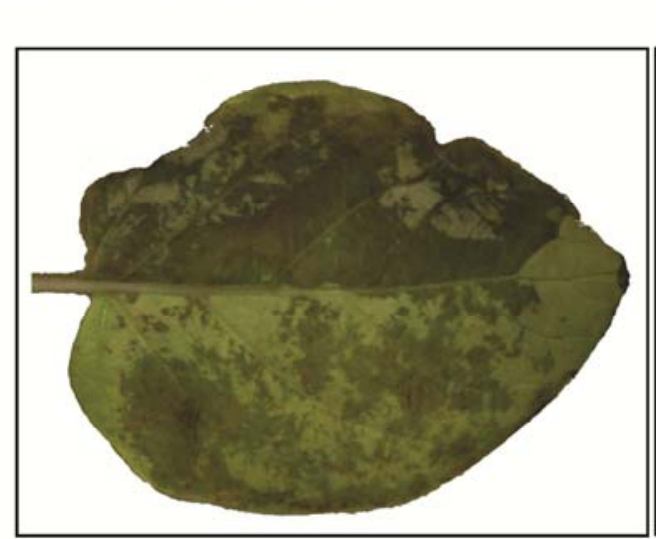

Desiree
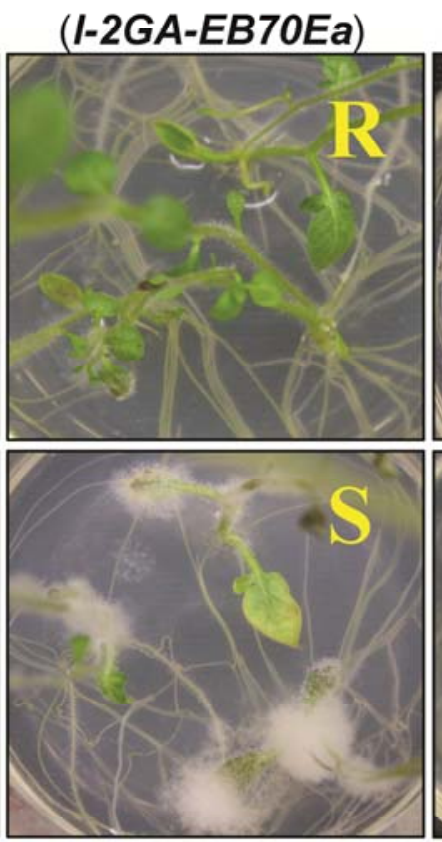

Desiree (I-2GA-SH193J21C)

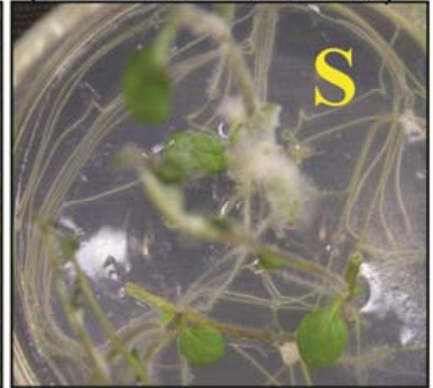

89148-9 (race 0)

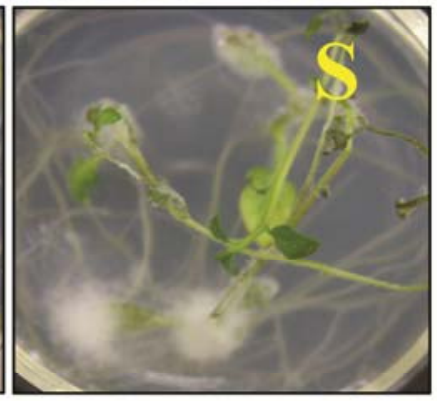

IPO- 0

(race 3b)

\section{Desiree}

\section{(I-2GA-EB70Ea)}

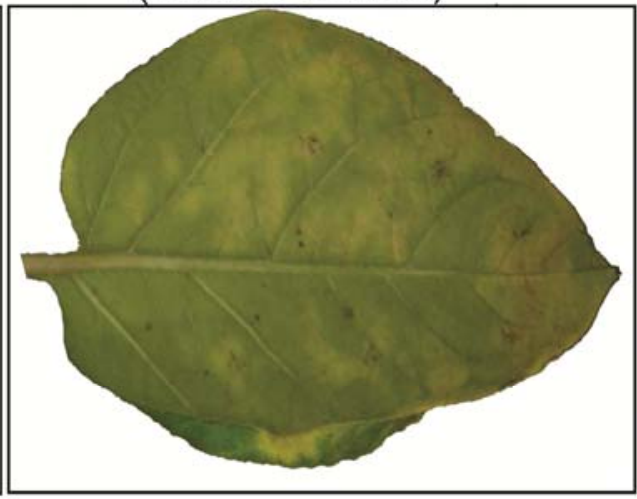

89148-9 (race 0)

\section{Dinteloord}

(race 1, 4)

Fig. 3. Functional complementation of Phytophthora infestans susceptibility in 'Desiree'. A, In vitro inoculation of the primary transformants of Desiree. Nontransgenic Desiree plants are susceptible to both isolates. Transgenic Desiree plants containing I-2 gene analog (GA)-EB70Ea are resistant to the isolate 89148-9. B, Detached leaf assay with greenhouse-grown transgenic Desiree plants. Desiree and Desiree stably transformed with $I$-2GA-EB70Ea were inoculated on the right side of the leaf with isolate 89148-09 and on the left side with isolate Dinteloord. The picture taken 6 days postinoculation is a representative photograph out of 50 individual transformed Desiree clones. 
2005), Rpi-blb3 (Lokossou et al. 2009), and Rpi-vnt1 (Pel et al. 2009) - showed less than $30 \%$ identity.

A phylogenetic analysis of the I-2 protein analogs described in this study and available homologous sequences from GenBank was performed. The Rpi-blb1 family of $\mathrm{R}$ proteins was used as an outgroup. Two distinct, bootstrap-supported clades of I-2 protein analogs could be distinguished (Fig. 6). The upper clade contained I-2 and the R3a protein and the lower clade contained the $\mathrm{R} 3 \mathrm{~b}$ protein. This fitted the assumption that $R 3 a$ and $R 3 b$, both located in the $R 3$ gene cluster, are clearly distinct, and together, they define a new $R$-gene superfamily.

\section{DISCUSSION}

\section{Location of $R 3 b$ in $R 3$ supercluster.}

$R 3 b$ was, like $R 3 a$, mapped to the distal part of the short arm of potato chromosome 11 in the diploid segregating population of $\mathrm{SH} \times \mathrm{RH}$ (Huang et al. 2004). The $R 3 b$ gene is located distal to marker GP185, whereas $R 3 a$ was located proximal to GP185. Like many other $R$ genes, $R 3 b$ resides in a hot spot for resistance to various pathogens. To date, the tomato $I-2$ gene encoding resistance to $F$. oxysporum and the $R 3 a$ gene conferring resistance to $P$. infestans were cloned from this region. In this study, we have shown that the $R 3 b$ gene encodes a CCNBS-LRR protein and is a paralog of $R 3 a$ (Huang et al. 2005a). $R 3 a$ and $R 3 b$ are located in the same $R 3$ supercluster, separated by $0.4 \mathrm{cM}$. The physical distance in cis phase could not be determined because of a remaining gap in the BAC contig. In the trans phase, the $r 3 b$ and $r 3 a$ regions are estimated to be $550 \mathrm{~kb}$ apart. In addition to their physical distance, phylogenetic and genetic analysis showed that $R 3 a$ and $R 3 b$ regions are clearly distinct. The $R 3 b$ gene and 11 homologs form a clade in the tree (Fig. 6) that is clearly different from the clade that contains $R 3 a$ and $I-2$. Interestingly, all genes in the $R 3 b$ clade are located distal to marker GP185.

\section{Evolution of the $R 3 \boldsymbol{b}$ subcluster.}

The $R 3 b$ gene is most similar to $I-2 G A-S H 193 J 21 c$, exhibiting $97.7 \%$ nucleotide identity. Comparison of the $R 3 \mathrm{~b}$ and $I$ 2GA-SH193J21c sequences showed that these two genes may have undergone two sequence exchanges because of an unequal distribution of single-nucleotide polymorphisms (SNP). The first exchange tract $(1,403 \mathrm{bp}$, from +7 to $+1,409$ of the $R 3 b$ gene) showed only three SNP between the two genes, and the second exchange tract $(+1,907$ to $+2,598)$ was identical in the two genes. Therefore, the $R 3 b$ gene seems to have an evolutionary pattern of type I $R$ genes (Kuang et al. 2004). I-2GA$E B 70 E b$ and $I-2 G A-S H 193 J 21 b$, which are physically separating $R 3 b$ from its closest homolog, I-2GA-SH193J21c, are highly similar and contain insertions of retrotransposons at identical positions in their coding regions. We hypothesize that I-2GA-SH193J2I $a$ and I-2GA-SH193J21c duplicated to form $R 3 b$ and $I-2 G A-E B 70 E b$. Successively, two retrotransposons $(10.8 \mathrm{~kb}$ total) were inserted into $I-2 G A-E B 70 b$. $I-2 G A$ $E B 70 E b$ was then duplicated to form $I-2 G A-S H 193 J 21 b$, and the latter product lost, successively, $8 \mathrm{~kb}$ of the retrotransposon sequence. These proposed sequential duplication events have been indicated in Figure 2 by hatched arrows.

\section{Lack of synteny between haplotypes in $R 3 b$ region.}

The comparison of the $R 3 b$ region in three haplotypes ( $\mathrm{SH}$ cis, SH trans, and S. demissum) showed that this region varies dramatically. Six $I-2 \mathrm{GA}$ were present in the $488 \mathrm{-kb}$ sequence at the $R 7$ region in $S$. demissum (contig PGEC152I5-400L14; accession PI161729), of which three are complete genes (Table 2). In this study, $10 \mathrm{I}-2 \mathrm{GA}$ were identified from BAC $\mathrm{SH} 159 \mathrm{~B} 22$ and $\mathrm{SH} 27 \mathrm{O} 14$ in the $r 3 b$ region, of which 5 were full-length genes. The $R 3 b$ region in SH (BAC clones SH96A7, EB70E, and SH193J21) harbors eight I-2GA, of which four are full-length genes (Table 2). SH96A7 is allelic to BAC542 in the PGEC152I5-400L14 contig from S. demis-
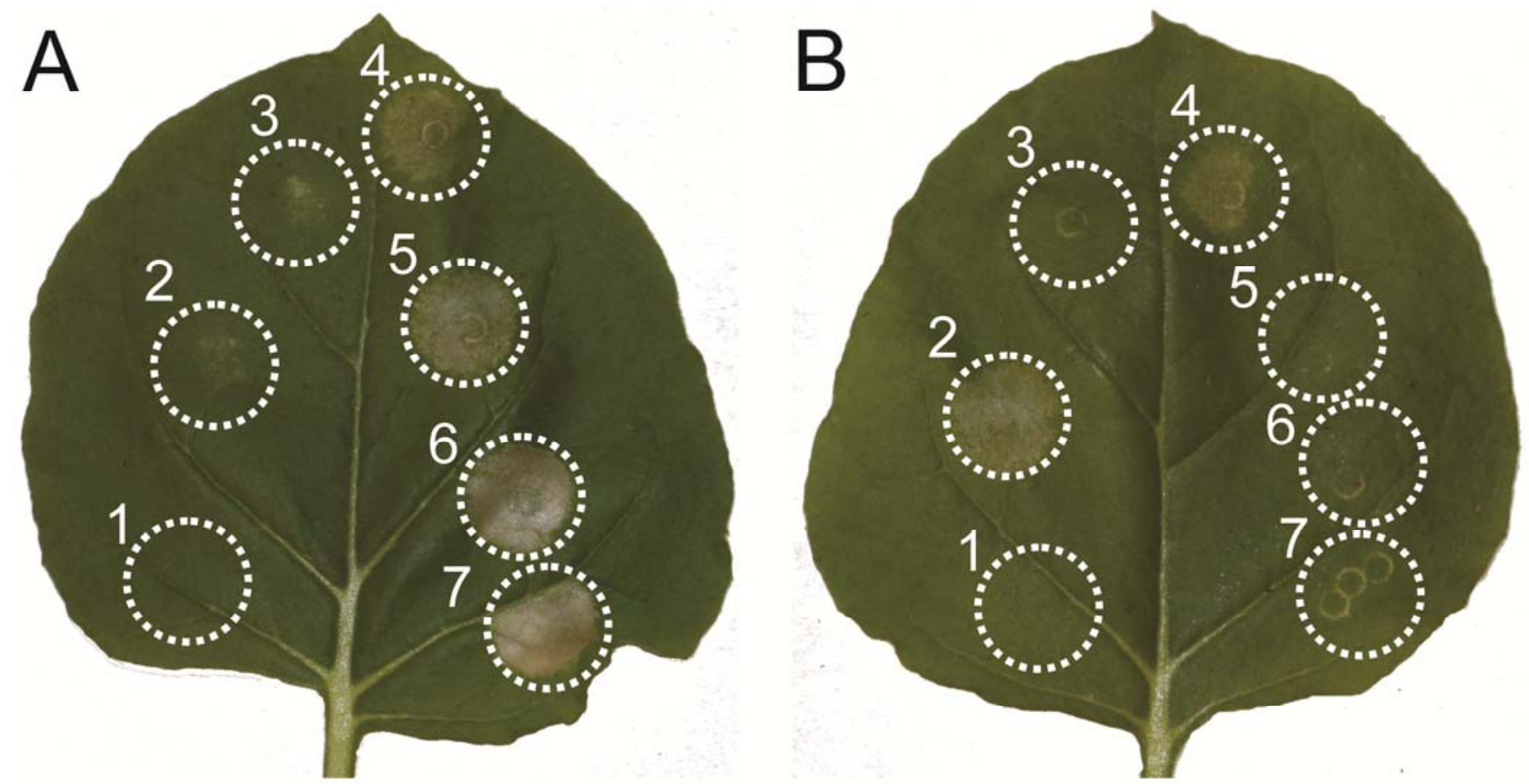

Fig. 4. $R 3 b$ and $R 3 a$ effector recognition specificity. Nicotiana benthamiana leaves were co-agroinfiltrated with avirulence (Avr) effectors and the potato resistance gene $\mathbf{A}, R 3 b$ and $\mathbf{B}, R 3 a$. The following constructs were co-infiltrated with the resistance $(R)$ genes: $1, R+$ pMDC 32 empty plasmid (negative control); 2, $R+$ Avr3aKI; 3, $R+$ AVR2; 4, $R 3 a+$ Avr3aKI (positive control); 5-7, $R+$ PITG_18215. Co-infiltration was accomplished using a mixture of equal amounts of Agrobacterium strains. All bacterial densities were set to an optical density at $600 \mathrm{~nm}\left(\mathrm{OD}_{600}\right)$ of 0.2 for spots $1-5$. Spots 6 and 7 were infiltrated at $\mathrm{OD}_{600}=0.5$ and 1.0, respectively. Photographs were taken 4 days postinfiltration. 
sum, both harboring the marker GP185 and three I-2GA. More distally, microsynteny was sparse in different haplotypes, and no allelic relationship could be determined for the genes in this region, similar to the $R I$ locus in $S$. demissum (Kuang et al.

CC

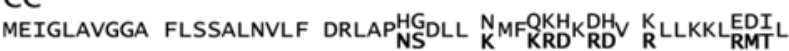

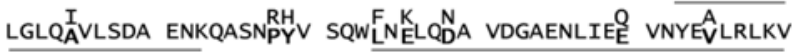

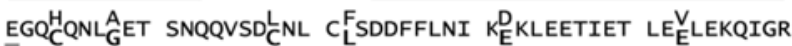
L $_{\text {DL }}^{\text {KEKYLEG }} S_{G}^{\top}$ KQETRES

NBS $S_{T} S_{\mathbf{V}}^{L} V D_{E}^{D} S D I \quad F_{L} G R Q N D_{E}^{D} I E_{G}^{D} L$ IDRLLSED

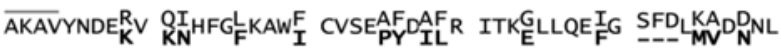

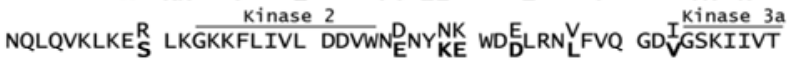

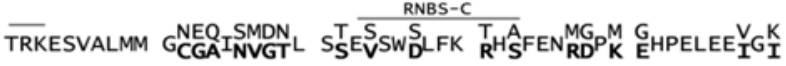

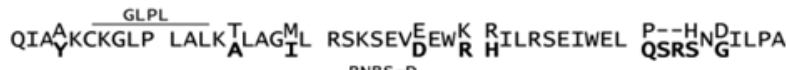

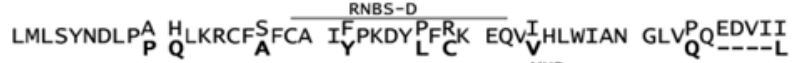

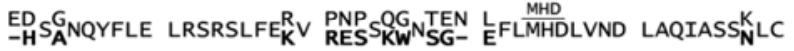

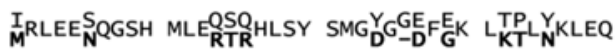

\begin{tabular}{|c|c|c|c|}
\hline \multicolumn{2}{|c|}{ LRR } & $X X L X L X X$ & \\
\hline 1 & -LRTLLP & $\begin{array}{l}\text { TC I ILPD } \\
\text { IN }{ }_{Q R R P}\end{array}$ & $\mathrm{C}_{-}^{\mathrm{CH}} \mathrm{HL}_{\mathrm{K}}^{\mathrm{S}} \mathrm{KR} \stackrel{\mathrm{V}}{\mathrm{V}} \mathrm{LH}_{\mathrm{D}}^{\mathrm{N}} \mathrm{I}$ \\
\hline 2 & $-P R L{ }_{I}^{T} S L$ & RALSLS $_{\mathbf{P}}^{C}$ & $\mathrm{Y}_{\mathrm{D}}^{\mathrm{E}} \mathrm{I}_{\mathrm{E}}^{\mathrm{V}} \mathrm{ELPNDL}_{\mathrm{L}}$ \\
\hline 3 & FIKLKK $K_{H}^{L} \mathrm{~L}$ & ${ }_{\mathrm{K}}^{\mathrm{R}} \mathrm{FLD} \mathrm{D}_{\mathrm{L}}^{\mathrm{I}} \mathrm{S}_{\mathrm{W}}^{\mathrm{R}}$ & $\mathrm{T}_{\mathrm{Q}}^{\mathrm{E}} \mathrm{I}_{\mathrm{K}}^{\mathrm{R}} \mathrm{RLPDS}$ \\
\hline 4 & $I C_{E}^{A} L Y_{S}^{N}$ & $E_{I}^{T} L_{I} L_{T} S_{H}^{S}$ & $\mathrm{C}_{S}^{\mathrm{YD}} \mathrm{L}_{\mathrm{N}} \mathrm{E}_{\mathrm{P}}^{\mathrm{L}} \mathrm{PLQ}$ \\
\hline 5 & MEKLINL & ${ }_{H}^{R} H L D_{V}^{I} S_{D}^{N}$ & $\begin{array}{l}\text { TRLLLKM PLH } \\
\text { AYF }\end{array}$ \\
\hline 6 & $--\frac{\mathrm{L}}{\mathrm{V}} \mathrm{SKL}$ & $K_{N}^{S} L_{H}^{Q} V L V$ & GAKF $_{F}^{-} L_{T}^{I} G_{S S G L}^{G L} R_{I}^{M}$ \\
\hline 7 & $\mathrm{GE}_{\mathrm{L}}^{\mathrm{V}} \mathrm{HNLY}$ & GSLS $\mathrm{IL}_{\mathrm{IL}}$ & LQNVVDRREAV KA \\
\hline 8 & MREKKN $_{\mathbf{K}}^{N} \mathrm{HV}$ & ${ }_{\text {E RL }}^{\text {PLLW }}$ & ${ }_{\mathrm{G}}^{\mathrm{S}} \mathrm{GS} \mathrm{SS}_{-\mathrm{F}} \mathrm{ADNSQTERDILDE}$ \\
\hline 9 & $\mathrm{~L}_{\mathrm{Q}}^{\mathrm{R}} \mathrm{F}_{\mathrm{NT}}^{\mathrm{HK}} \mathrm{NI}$ & $\mathrm{K}_{\mathrm{ELR}}^{\mathrm{VVK}} \mathrm{ITG}$ & YRGT ${ }_{K}^{N}$ FPNW \\
\hline 10 & $\mathrm{LAD}_{\mathrm{HS}}^{\mathrm{PL}} \mathrm{F}_{\mathrm{H}}^{\mathrm{L}}$ & KL & ${ }_{S Y}^{R N} C K_{D}^{N} C_{D}^{Y} S L P A L G Q L P F C K$ \\
\hline 11 & ${ }_{\mathrm{S}}^{\mathrm{F}} \mathrm{L} \mathrm{S}$ IREM & $\mathrm{H}_{\mathrm{Q}}^{\mathrm{G}} \mathrm{ITEV} \mathrm{S}_{\mathrm{S}}^{\top}$ & EEFYG $_{\mathrm{RF}}^{\mathrm{SW}} \mathrm{SS}$ \\
\hline 12 & $-\mathrm{KPFN}_{\mathrm{S}} \mathrm{L}$ & EKLEF $_{\mathrm{AE}}^{\mathrm{KD}}$ & MPEWKQWWHV DL \\
\hline 13 & $\mathrm{~K}_{\mathrm{K}}^{\mathrm{S}} \mathrm{EFP} \mathrm{V}_{\mathrm{V}}^{\mathrm{I}}$ & EE $^{\mathrm{K} L L I}$ & $\mathrm{CP}_{\mathrm{K}}^{\mathrm{E}} \mathrm{L} \mathrm{SL}$ \\
\hline 14 & I & $\begin{array}{l}\text { VKLDITD } \\
\text { KSFDVIG }\end{array}$ & $\begin{array}{l}\text { CKSLTSLPI } \\
\text { SPLVINFPL }\end{array}$ \\
\hline 15 & $-\cdots--$ & KSFDVIG & SPLVINFPL \\
\hline 16 & SILPTSTL & $\mathrm{KRI} \mathrm{R}_{\mathrm{R}}^{\mathrm{K}} \mathrm{I}_{\mathrm{AF}}^{\mathrm{SD}}$ & $\mathrm{C}_{\mathrm{GE}}^{\mathrm{QK}} \mathrm{LKLE} \mathrm{-}_{--}^{\mathrm{QP}}$ \\
\hline 17 & $\begin{array}{l}\text { GEIS MFL } \\
\text { SMNA }\end{array}$ & 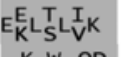 & $\mathrm{CD}_{-}^{\mathrm{CIDDI}} \mathrm{SP}$ \\
\hline 18 & $-E L_{V}^{L}$ PRA & $R_{N}^{K} L_{S}^{W} V_{R S}^{Q D}$ & CN NLTRFL \\
\hline 19 & --IPTAT & $E_{R}^{\top} L_{S}^{D} I_{R D}^{W N}$ & YEDNEILSV \\
\hline 20 & $A_{R-G T Q M}^{C G G}$ & $\mathrm{TSL}_{N}^{\top} \mathrm{I}_{\mathrm{YD}}^{\mathrm{AY}}$ & CKKLKW W \\
\hline 21 & QELLPSL & K ${ }_{K}^{E} L_{V V Q N A}$ & CPEIESFPEGGLP \\
\hline 22 & --- FNL & $Q_{A}^{Q} L_{S}^{A} I_{W N}^{R Y}$ & CKKLVNGRK \\
\hline 23 & $\operatorname{LQR}_{\mathrm{LPS}}^{R L} \mathrm{~L}$ & IA LITIYH & DGSDEE VLA GE \\
\hline 24 & $--\operatorname{LP} P_{C}^{S} S I$ & ${ }_{R}^{Q_{R}} R L T I_{S}^{v}$ & LKTLSSQ \\
\hline 25 & LKN ${ }_{S}^{N T S L}$ & ${ }_{E}^{\text {Q Y Y }} L_{D A}^{F I} R_{-}^{G}$ & 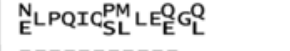 \\
\hline 26 & $\begin{array}{l}\text { PFSLSL } \\
\text { CSHLTSL }\end{array}$ & $\begin{array}{l}\text { SELILFS } \\
\text { OSLOISS }\end{array}$ & NHDLHSLPTEG \\
\hline 27 & CSHLTSL & & - \\
\hline 28 & $\begin{array}{l}\text { SALPSS } \\
\text { LQHLTW }\end{array}$ & RR LEISH & CPN ${ }_{S}^{N} L Q S L P E$ \\
\hline 29 & $S_{G}^{A}$ LPSSL & $S_{E}^{Q} L_{G}^{T} I_{W}^{N} N$ & $C_{S}^{P}$ NLQSLS \\
\hline 30 & STLF & SQLEISF & CPNLQYLPL \\
\hline 31 & $\mathrm{~K}_{\mathrm{S}}^{\mathrm{K}} \mathrm{GM}$ & $\mathrm{S}_{\mathrm{K}}^{\mathrm{E}} \mathrm{L}_{\mathrm{R}}^{\mathrm{S}} \mathrm{I}_{\mathrm{SE}}^{\mathrm{YK}}$ & CPLLKPQLEE \\
\hline & $\mathrm{F}_{\mathrm{N}}^{\mathrm{K}}$ & & $I_{K}^{R} E_{Y Q}^{R C M}$ \\
\hline
\end{tabular}

2005) and the RPP5 locus (Noel et al. 1999) in Arabidopsis thaliana. This apparent lack of synteny between haplotypes severely delayed the physical map construction of the $R 3 b$ region, because the markers located in the $r 3 b$ region (except for marker $51 \mathrm{~T}$ ) could not be used to find cis phase BAC in the $R 3 b$ region.

\section{Functional diversification between $R 3 a$ and $R 3 b$.}

In potato, most of the $R$ genes belong to complex $R$-gene clusters with tightly linked paralogs (Gebhardt and Valkonen 2001). Large arrays of similar sequences allow for equal or unequal recombination events, resulting in the formation of new gene clusters (Hulbert et al. 2001). However, the evolutionary fate of new members in complex resistance loci may largely depend on the interaction between the plant and its pathogens. In gene-for-gene interactions, plant $\mathrm{R}$ proteins recognize the pathogen $A v r$ or effector proteins either through direct $\mathrm{R}-\mathrm{Avr}$ protein-protein interaction or indirectly through detection of modifications of host proteins targeted by effectors, the so-called guardee proteins in the guard model (Jones and Dangl 2006; McDowell and Simon 2006). Host-pathogen co-evolution will lead to hosts evolving new specificities in their $\mathrm{R}$ proteins to identify the corresponding Avr factors as well as pathogens altering their Avr factors to avoid R-mediated recognition (Parker and Gilbert 2004).

Most $R$-gene clusters contain only one $R$ gene with a described function. Only a few $R$-gene clusters comprise more than one described functional $R$ gene (Botella et al. 1998; Dixon et al. 1996; Rouppe et al. 1999; Takken et al. 1999). In addition to the Rpi-mcd1/Rpi-blb3 locus on chromosome 4, the $R 3$ locus is the second example of an $R$-gene cluster with multiple genes recognizing different races of $P$. infestans (Lokossou 2010).

Reported mechanisms resulting in conversion of Avr to $a v r$ include nucleotide substitutions, insertions, and deletions. The $R$ genes corresponding to the $A v r$ genes may also be mutated through point mutations, insertions, and deletions to change into nonresistance genes. In this article, the $R 3 b$ gene and $I$ 2GA-SH193J21C have an identity of $97.7 \%$ but $I-2 G A-$ SH193J21c showed no resistance function with the late blight isolates tested.

$R 3 a$ was triggered in the host cytoplasm by the Avr3a gene (Armstrong et al. 2005) to exhibit hypersensitive cell death. Because of the high level of sequence conservation between $R 3 a$ and $R 3 b$, and because $A v r 3 b$ encodes an RXLR protein, which is predicted to be sequestered into the host cytoplasm, it can be postulated that $R 3 b$ has a resistance mechanism similar to $R 3 a$. Its recognition specificity, however, is clearly different because $R 3 b$ does not recognize $A v r 3 a$ (Fig. 4A) and $R 3 a$ does not recognize $A v r 3 b$ (Fig. 4B). This is supported by studies with specific isolates for $R 3 a$ and $R 3 b$ by Huang and associates (2005a). The low extent of homology in the LRR domains of R3a and R3b compared with the CC and NBS domains suggests that the LRR domain may be involved in pathogen recognition, as is the case in other R proteins (Burch-Smith et al. 2007; Jones and Dangl 2006; Lokossou 2010).

Fig. 5. Primary structure and alignment of the $R 3 a$ and $R 3 b$ resistance proteins. Amino acid residues of $R 3 a$ and $R 3 b$ that are identical are shown in normal script. R3a- and R3b-specific residues are shown in bold at top and bottom lines, respectively. Dashes indicate gaps to fit the alignment. The predicted coiled coils (Lupas et al. 1991) in the coiled-coil domains are underlined. The conserved motifs of the nucleotide-binding site domain are overlined. The consensus xxLxLxx of each leucine-rich repeat is highlighted with a gray background. 
Of the $11 S$. demissum $R$ genes, $R 3$ (including $R 3 a$ and $R 3 b), R 6, R 7, R 10$, and $R 11$ have been mapped on chromosome 11 (Bradshaw et al. 2006; El-Kharbotly et al. 1996; Huang et al. 2004). $R 5, R 8$, and $R 9$ also have been shown to contain the $R 3$ gene locus (Huang et al. 2005a). It will be interesting to know why so many $R$ genes locate on chromosome 11 , most likely in the $R 3$ supercluster. Additional research investigating functional diversity of the respective $S$. demissum $R$ genes might be greatly facilitated by the identification of their cognate Avr component.

\section{Implications for plant breeding.}

Though many $R$ genes were identified in different species and several $R$ genes have successfully been transferred to cultivated potato (Golas et al. 2010; Huang et al. 2005a; Pel et al. 2009; Sliwka et al. 2010; van der Vossen et al. 2003), it is generally assumed that individual $R$ genes are easily overcome by the variable pathogen $P$. infestans. Stacking of $R$ genes with broadspectrum major resistance genes could be a desirable solution (Lokossou 2010; Rauscher et al. 2010; Stewart et al. 2003; Tan et al. 2010). However, selection for functional stacking of $R$ genes in a susceptible cultivar is highly dependent on the availability of the corresponding $A v r$ genes, as has been shown in triple $R$-gene transformants of Desiree by Zhu and associates (2010). This combined availability is fortunately the case with more and more cloned $R$ genes. Cloning of both $R 3 b$ and $A v r 3 b$ will provide great help to characterize the $R 3$ gene cluster in Solanum spp. and will promote additional $R$-gene cloning in this region. Newly cloned $R$ genes from the $R 3$ gene cluster will be deployed as stacked cisgenic $R$ genes for the improvement of existing potato cultivars using marker-free genetically modified organism techniques (Jacobsen and Schouten 2007).

\section{MATERIALS AND METHODS}

\section{Plant material.}

The $\mathrm{F} 1$ population of $\mathrm{SH} \times \mathrm{RH}$ that segregates for both $R 3 a$ and $R 3 b$ was used for genetic mapping (Huang et al. 2004). The susceptible potato clone Desiree was used for genetic transformation.

\section{$P$. infestans isolates and inoculation.}

P. infestans isolates 89148-09 (Avr3a and Avr3b), IPO-0 (Avr3a and avr3b), and Dinteloord (Avr3b) were inoculated on transgenic in vitro plantlets, on $N$. benthamiana plants, or on leaves of transgenic, greenhouse-grown plants in DLA (Huang et al. 2004).

\section{Genetic mapping.}

In total, 3,000 $\mathrm{SH} \times \mathrm{RH}$ progeny were screened for recombinants in the $R 3$ region using the flanking markers cLET5E4 and CT120 (Table 1). In order to get the recombinants of the $R 3 b$ region, the selected recombinants were screened further using flanking markers GP185 and 656T (Table 1). The selected $R 3 b$ region recombinants were used to determine the position of the $R 3 b$ AFLP markers (Fig. 1). DNA isolation and analysis of molecular markers were as described by Huang and associates (2004).

In the 10,000-marker UHD map, "Bin" instead of centimorgan as the genetic distance unit has been introduced. Bin is defined as a genetic interval flanked by a recombination event on either side (van Os et al. 2006). The population size of the UHD map was 130; thus, a Bin is roughly equivalent to $0.8 \mathrm{cM}$.

\section{Physical mapping.}

Two BAC libraries of the resistant parent SH were constructed with different restriction enzymes HindIII and EcoRI according to the previously described protocol (Rouppe van der Voort et al. 1999). The HindIII BAC library (10x coverage of SH genome) was stored in 255 384-well microtiter plates and their BAC clones were named with prefix $\mathrm{SH}$. The

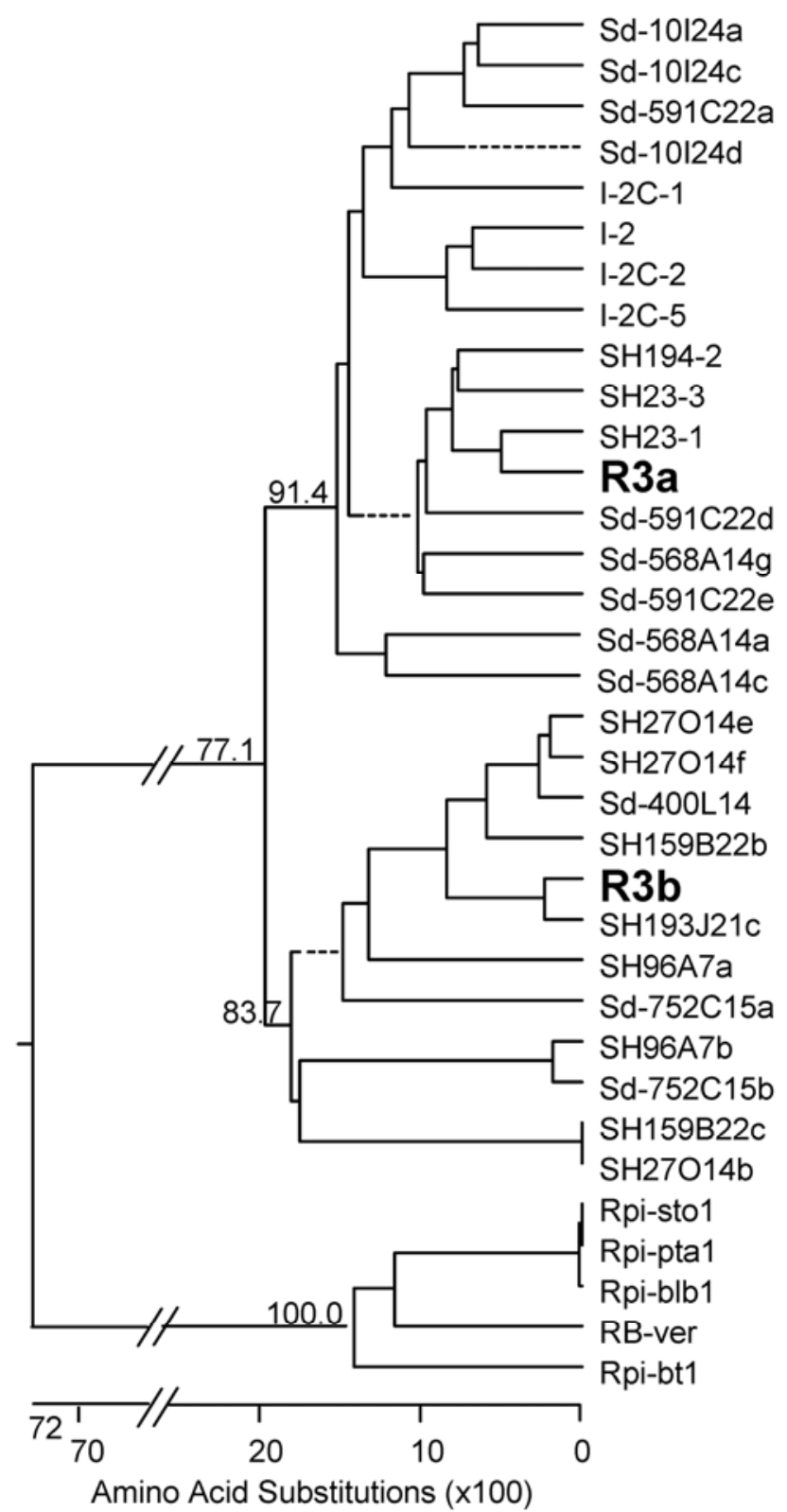

Fig. 6. Phylogenetic analysis of R3 protein superfamily. R3b homologs were derived from various sources as described in the text. $S d$ - sequences were derived from Solanum demissum contig PGEC152I15-400L14 and additional sources $(10 \mathrm{I} 24 \mathrm{a}=\mathrm{EF} 613516 ; 10 \mathrm{I} 24 \mathrm{c}=\mathrm{EF} 613518 ; 10 \mathrm{I} 24 \mathrm{~d}=\mathrm{EF} 613519$; 568A14g = EF613544; 591C22a, d, e = AC151801). R3a, I-2 gene analog (GA)-SH194-2, and I-2GA-SH23 sequences were derived from bacterial artificial chromosomes SH83-92-488, SH194C17, and SH23G23, respectively (Huang et al. 2005a). I-2 like sequences from tomato were I-2 (AF118127), I2C-1 (AF004878), I2C-2 (AF004879), and I2C-5 (AF408704). Other SH sequences were identified in this study: SH159B22-b = EF638450; SH159B22-c = EF638451; SH27O14e = EF638455; SH27O14f = EF638456; SH27O14b = EF638454; SH96A7a = EF638458; SH96A7b = EF638464; SH193J21c = EF638453; EB70Ea = R3b = HQ437670; Rpi-blb1 and Rpi-sto1 = EU884421 and Rpi-pta1 = EU884422 (Vleeshouwers et al. 2008); RB-ver = EF202329 (Liu and Halterman 2006); and Rpi-bt1 = FJ188415 (Oosumi et al. 2009). Alignments were performed according to the Clustal $\mathrm{W}$ algorithm and the closest related gene family, founded by Rpi-blb1, was used as an outgroup. Successively, a bootstrapped distance tree was calculated using 1,000 jumbles and seed = 111 using Megalign from the DNAstar software package. 
EcoRI BAC library ( $33 \times$ coverage of SH genome) was stored in 80 super pools, each superpool contained 4,000 to 5,000 clones, and their BAC clones were named with prefix EB.

Screening of the HindIII BAC library with $R 3 b$-region markers was performed as described previously (Huang et al. 2005a). Screening of the EcoRI BAC library was performed as follows. First, positive superpools ( 1 superpool $=4,000$ to 5,000 clones) were identified; second, pools ( 1 pool $=400$ to 500 clones) were made from those positive superpools; third, positive pools were identified; fourth, subpools ( 1 pool $=40$ to 50 clones) were made from those positive pools; fifth, positive subpools were identified; sixth, single positive clones were identified using colony PCR. Plasmid DNA was isolated using the standard alkaline-lysis protocol from superpooled, pooled, and subpooled bacteria to produce BAC DNA pools (Rouppe van der Voort et al. 1999).

Plasmids of single BAC were purified using MIDI-PREP columns (Qiagen, Hamburg, Germany). Sequences generated through BAC end sequencing with SP6, T7, FP, or RP primers were employed to design PCR primers to develop BAC end markers. The BAC end markers were named according to the BAC or pool number followed by S (SP6), T (T7), FP, or RP (Table 1). In view of the repetitive nature of the $R 3$ complex locus, the overlap of two BAC was verified by i) HindIII restriction mapping, ii) nonselective AFLP fingerprinting using HindIII and MseI/TaqI (Simons et al. 1998), and iii) analysis of BAC end markers through melting temperature gradient PCR restriction with 24 frequent cutters and sequencing of the PCR products.

\section{DNA sequencing and analysis.}

The BAC clones SH27O14, SH159B22, SH96A7, SH193J21, and EB70E (Fig. 2; Table 2) were sequenced by using a shotgun sequencing strategy. Positions of putative genes were predicted using GENSCAN (Burge and Karlin 1997) and GENEMARK (Lukashin and Borodovsky 1998). The alignments of multiple sequences were conducted by using CLUSTALW (Thompson et al. 1997).

\section{Subcloning and transformation of I-2GA.}

Candidate I-2GA were subcloned into the binary vector pBINPLUS (van Engelen et al. 1995) from the BAC clone EB70E and SH193J21 as described previously (van der Vossen et al. 2003). Binary plasmids harboring the candidate genes were transformed to Agrobacterium tumefaciens AGL0 (Lazo et al. 1991) and COR308 for transient complementation and introduced into Desiree according to standard protocols (Visser et al. 1991).

\section{Agroinfiltrations.}

Agroinfiltrations for transient expression of selected genes in $N$. benthamiana followed established protocols (van der Hoorn et al. 2000). For successive $P i$ inoculation, $R$-gene constructs were transformed into A. tumefaciens COR308. Bacteria were suspended in infiltration medium to an optical density at $600 \mathrm{~nm}\left(\mathrm{OD}_{600}\right)$ of 0.2 and infiltrated into the leaves of 4week-old $N$. benthamiana plants using a 2-ml syringe. Two days later, the leaves were collected and subjected to DLA. For $R$ gene/effector co-expression studies, A. tumefaciens AGL1+ VirG harbored the effector constructs and the $R$-gene constructs were in COR308. Bacteria were suspended in infiltration medium to $\mathrm{OD}_{600}=0.2$, mixed in a $1: 1$ ratio, and infiltrated into the leaves of 6-week-old $N$. benthamiana plants.

\section{Effector analysis.}

In a collaborative effort with the Sainsbury lab and Scottish Crop Research Institute, effectors were identified that were transcriptionally upregulated at 2 to 3 days postinoculation (Haas et al 2009) (Rietman 2011; a detailed description of the compilation of the effector collection will be published elsewhere). Of these, 150 effectors were selected and coding sequences were synthesized by Genscript Inc. (Piscataway, NJ, U.S.A.) in between AttL1 and AttL2 gateway recombination sites and cloned into pUC57. Sequences coding for putative secretion signal peptides were excluded and replaced with an ATG codon preceded by two nucleotides that would allow inframe N-terminal fusions for other applications. This effector collection was subcloned into pMDC32 using LR clonase (Invitrogen. San Diego, CA, U.S.A.) and transformed into A. tumefaciens AGL1+VirG. Construct EB70E-76, containing the $R 3 b$ gene, was used for co-agroinfiltration with individual members of this effector set. Upon recognition of the encoded effector by the $R$ gene, a hypersensitive response can be observed between 3 and 5 days postinoculation. As a control, we used $R 3 a$ and Avr3a-KI (Armstrong et al. 2005).

\section{ACKNOWLEDGMENTS}

We acknowledge the kind support of the National Natural Science Foundation of China (30971995 and 36171319) and Ministry of Science and Technology of China (2007DFB30080). G. Li, E. van der Vossen, and J. Vossen were supported by the DuRPh program granted by the Dutch ministry of Agriculture. We thank Z. Zhang (Chinese Academy of Agricultural Sciences) for bioinformatics analysis and P. Birch (Scottish Crop Research Institute, U.K.) and S. Kamoun (Sainsbury Lab, U.K.) for joint efforts in clompiling a genome-wide set of RXLR effectors from $P$. infestans.

\section{LITERATURE CITED}

Armstrong, M. R., Whisson, S. C., Pritchard, L., Bos, J. I. B., Venter, E., Avrova, A. O., Rehmany, A. P., Bohme, U., Brooks, K., Cherevach, I., Hamlin, N., White, B., Frasers, A., Lord, A., Quail, M. A., Churcher, C., Hall, N., Berriman, M., Huang, S., Kamoun, S., Beynon, J. L., and Birch, P. R. J. 2005. An ancestral oomycete locus contains late blight avirulence gene $A v r 3 a$, encoding a protein that is recognized in the host cytoplasm. Proc. Natl. Acad. Sci. U.S.A. 102:7766-7771.

Ballvora, A., Ercolano, M. R., Weiss, J., Meksem, K., Bormann, C. A., Oberhagemann, P., Salamini, F., and Gebhardt, C. 2002. The Rl gene for potato resistance to late blight (Phytophthora infestans) belongs to the leucine zipper/NBS/LRR class of plant resistance genes. Plant J. 30:361-371.

Boller, T., and He, S. Y. 2009. Innate immunity in plants: An arms race between pattern recognition receptors in plants and effectors in microbial pathogens. Science 324:742-744.

Botella, M. A., Parker, J. E., Frost, L. N., Bittner, E. P. D., Beynon, J. L., Daniels, M. J., Holub, E. B., and Jones, J. D. G. 1998. Three genes of Arabidopsis RPP1 complex resistance locus recognize distinct Peronospora parasitica avirulence determinants. Plant Cell 10:1847-1860.

Bradshaw, J. E., Bryan, G. J., Lees, A. K., McLean, K., and SolomonBlackburn, R. M. 2006. Mapping the R10 and R11 genes for resistance to late blight (Phytophthora infestans) present in the potato (Solanum tuberosum) R-gene differentials of Black. Theor. Appl. Genet. 112:744751.

Burch-Smith, T. M., Schiff, M., Caplan, J. L., Tsao, J., Czymmek, K., and Dinseh-Kumar, S. P. 2007. A novel role for the TIR domain in association with pathogen-derived elicitors. PLoS Biol. 5:e68.

Burge, C., and Karlin, S. 1997. Prediction of complete gene structures in human genomic DNA. J. Mol. Biol. 268:78-94.

Dangl, J. L., and Jones, J. D. G. 2001. Plant pathogens and integrated defense responses to infection. Nature 411:826-833.

Dixon, M. S., Jones, D. A., Keddie, J. S., Thomas, C. M., Harrison, K., and Jones, J. D. 1996. The tomato $c f-2$ disease resistance locus comprises two functional genes encoding leucine-rich repeat proteins. Cell 84:451-459.

El Kharbotly, A., Leonards-Schippers, C., Huigen, D. J., Jacobsen, E., Pereira, A., Stiekema, W. J., Salamini, F., and Gebhardt, C. 1994. Segregation analysis and RFLP mapping of the $R 1$ and $R 3$ alleles conferring race-specific resistance to Phytophthora infestans in progeny of dihaploid potato parents. Mol. Gen. Genet. 242:749-754.

El Kharbotly, A., Palomino Sanchez, C., Salamini, F., Jacobsen, E., and Gebhardt, C. 1996. $R 6$ and $R 7$ alleles of potato conferring race-specific 
resistance to Phytophthora infestans (Mont.) de Bary identified genetic loci clustering with the $R 3$ locus on chromosome XI. Theor. Appl. Genet. 92:880-884.

Fry, W. 2008. Phytophthora infestans: The plant (and $R$ gene) destroyer. Mol. Plant Pathol. 9:385-402.

Golas, T. M., Sikkema, A., Gros, J., Feron, R. M., van den Berg, R. G., van der Weerden, G. M., Mariani, C., and Allefs, J. J. 2010. Identification of a resistance gene Rpi-dlcl to Phytophthora infestans in European accessions of Solanum dulcamara. Theor. Appl. Genet. 120:797808.

Gebhardt, C., and Valkonen, J. P. 2001. Organization of genes controlling disease resistance in the potato genome. Annu. Rev. Phytopathol. 39:79102.

Haas, B. J., Kamoun, S., Zody, M. C., Jiang, R. H., Handsaker, R. E., Cano, L. M., Grabherr, M., Kodira, C. D., Raffaele, S., Torto-Alalibo, T., Bozkurt, T. O., Ah-Fong, A. M., Alvarado, L., Anderson, V. L., Armstrong, M. R., Avrova, A., Baxter, L., Beynon, J., Boevink, P. C., Bollmann, S. R., Bos, J. I., Bulone, V., Cai, G., Cakir, C., Carrington, J. C., Chawner, M., Conti, L., Costanzo, S., Ewan, R., Fahlgren, N., Fischbach, M. A., Fugelstad, J., Gilroy, E. M., Gnerre, S., Green, P. J., Grenville-Briggs, L. J., Griffith, J., Grunwald, N. J., Horn, K., Horner, N. R., Hu, C. H., Huitema, E., Jeong, D. H., Jones, A. M., Jones, J. D., Jones, R. W., Karlsson, E. K., Kunjeti, S. G., Lamour, K., Liu, Z., Ma, L., Maclean, D., Chibucos, M.C., McDonald, H., McWalters, J., Meijer, H. J., Morgan, W., Morris, P. F., Munro, C. A., O’Neill, K., Ospina-Giraldo, M., Pinzon, A., Pritchard, L., Ramsahoye, B., Ren, Q., Restrepo, S., Roy, S. Sadanandom, A., Savidor, A., Schornack, S., Schwartz, D. C., Schumann, U. D., Schwessinger, B., Seyer, L., Sharpe, T., Silvar, C., Song, J., Studholme, D. J., Sykes, S., Thines, M., van de Vondervoort, P. J., Phuntumart, V., Wawra, S., Weide, R., Win, J., Young, C., Zhou, S., Fry, W., Meyers, B. C., van West, P., Ristaino, J., Govers, F., Birch, P. R. Whisson, S. C., Judelson, H. S., and Nusbaum, C. 2009. Genome sequence and analysis of the Irish potato famine pathogen Phytophthora infestans. Nature 461:393-398.

Haverkort, A. J., Boonekamp, P. M., Hutten, R., Jacobsen, E., Lotz, L. A., Kessel, G. J., Visser, R. G., and van der Vossen, E. A. 2008. Societal costs of late blight in potato and prospects of durable resistance through cisgenic modification. Potato Res. 51:47-57.

Huang, S., Vleeshouwers, V. G., Werij, J. S., Hutten, R. C., van Eck, H. J., Visser, R. G., and Jacobsen, E. 2004. The $R 3$ resistance to Phytophthora infestans in potato is conferred by two closely linked $R$ genes with distinct specificities. Mol. Plant-Microbe Interact. 17:428-435.

Huang, S., van der Vossen, E., Kuang, H., Vleeshouwers, V. G., Zhang, N., Borm, T. J., Van Eck, H. J., Baker, B., Jacobsen, E., and Visser, R. 2005a. Comparative genomics enabled the cloning of the $R 3 a$ late blight resistance gene in potato. Plant J. 42:261-271.

Hulbert, S. H., Webb, C. A., Smith, S. M., and Sun, Q. 2001. Resistance gene complexes: Evolution and utilization. Annu. Rev. Phytopathol. $39: 285-312$.

Isidore, E., van Os, H., Andrzejewski, S., Bakker, J., Barrena, I., Bryan, G. J., Caromel, B., van Eck, H., Ghareeb, B., de Jong, W., van Koert, P., Lefebvre, V., Milbourne, D., Ritter, E., van der Voort, J. R., RousselleBourgeois, F., van Vliet, J., and Waugh, R. 2003. Toward a markerdense meiotic map of the potato genome: Lessons from linkage group I. Genetics 165:2107-2116.

Jacobsen, E., and Hutten, R. 2006. Stacking resistance genes in potato by cisgenesis instead of introgression breeding. Pages 46-57 in: Potato Developments in a Changing Europe. N. U. Haase and A. J. Haverkort, eds. Wageningen Academic Publishers, Wageningen, The Netherlands.

Jacobsen, E., and Schouten, H. J. 2007. Cisgenesis strongly improves introgression breeding and induced translocation breeding of plants. Trends Biotechnol. 25:219-223.

Jones, J. D. G., and Dangl, J. L. 2006. The plant immune system. Nature 444:323-329

Kuang, H., Woo, S. S., Meyers, B. C., Nevo, E., and Michelmore, R. W. 2004. Multiple genetic processes result in heterogeneous rates of evolution within the major cluster disease resistance genes in lettuce. Plant Cell 16:2870-2894.

Kuang, H., Wei, F., Marano, M. R., Wirtz, U., Wang, X., Liu, J., Shum, W. P., Zaborsky, J., Tallon, L. J., Rensink, W., Lobst, S., Zhang, P., Tornqvist, C. E., Tek, A., Bamberg, J., Helgeson, J., Fry, W., You, F., Luo, M. C., Jiang, J., Robin Buell, C., and Baker, B. 2005. The Rl resistance gene cluster contains three groups of independently evolving, type I $R I$ homologues and shows substantial structural variation among haplotypes of Solanum demissum. Plant J. 44:37-51.

Lazo, G. R., Stein, P. A., and Ludwig, R. A. 1991. A DNA transformationcompetent Arabidopsis genomic library in Agrobacterium. Biotechnology 9:963-967.

Liu, Z., and Halterman, D. 2006. Identification and characterization of RB-orthologous genes from the late blight resistant wild potato species
Solanum verrucosum. Physiol. Mol. Plant Pathol. 69:230-239.

Lokossou, A. A. 2010. Dissection of the major late blight resistance cluster on potato linkage group IV. Pages 71-90 in: Ph.D. thesis, Wageningen University, The Netherlands.

Lokossou, A. A., Park, T. H., van Arkel, G., Arens, M., Ruyter-Spira, C., Morales, J., Whisson, S. C., Birch, P. R. J., Visser, R. G. F., Jacobsen, E., and van der Vossen, E. A. G. 2009. Exploiting knowledge of R/Avr genes to rapidly clone a new LZ-NBS-LRR family of late blight resistance genes from potato linkage group IV. Mol. Plant-Microbe Interact. 22:630-641.

Lukashin, A. V., and Borodovsky, M. 1998. GeneMark.hmm: New solutions for gene finding. Nucleic Acids Res. 26:1107-1115.

McDonald, B. A., and Linde, C. 2002. Pathogen population genetics, evolutionary potential, and durable resistance. Annu. Rev. Phytopathol. 40:349-379.

McDowell, J. M., and Simon, S. A. 2006. Recent insights into $R$ gene evolution. Mol. Plant Pathol. 7:437-448.

Noel, L., Moores, T. L., van der Biezen, E. A., Parniske, M., Daniels, M. J., Parker, J. E., and Jones, J. D. G. 1999. Pronounced intraspecific haplotype divergence at the RPP5 complex disease resistance locus of Arabidopsis. Plant Cell 11:2099-2111.

Oh, S.-K., Young, C., Lee, M., Oliva, R., Bozkurt, T., Cano, L. M., Win, J., Bos, J. I. B., Liu, H.-Y., van Damme, M., Morgan, W., Choi, D., van der Vossen, E. A. G., Vleeshouwers, V., and Kamoun, S. 2009. In planta expression screens of Phytophthora infestans RXLR effectors reveal diverse phenotypes, including activation of the Solanum bulbocastanum disease resistance protein Rpi-blb2. Plant Cell 21:20282947.

Oosumi, T., Rockhold, D. R., Maccree, M. M., Deahl, K. L., McCue, K. F., and Belknap, W. R. 2009. Rpi-bt1 from Solanum bulbocastanum confers resistance to late blight in transgenic potatoes. J. Potato Res. 86:456-465.

Parker, I. M., and Gilbert, G. S. 2004. The evolutionary ecology of novel plant-pathogen interactions. Annu. Rev. Ecol. Evol. Syst. 35:675-700.

Pel, M. A., Foster, S. J., Park, T. H., Rietman, H., van Arkel, G., Jones, J. D., Van Eck, H. J., Jacobsen, E., Visser, R. G., and Van der Vossen, E. A. 2009. Mapping and cloning of late blight resistance genes from Solanum venturii using an interspecific candidate gene approach. Mol. Plant-Microbe Interact. 22:601-615.

Rauscher, G., Simko, I., Mayton, H., Bonierbale M., Smart, C. D., Grünwald, N. J., Greenland, A., and Fry, W. E. 2010. Quantitative resistance to late blight from Solanum berthaultii cosegregates with $R_{P i-b e r}$ : Insights in stability through isolates and environment. Theor. Appl. Genet. 121:1553-1567.

Reader, J. 2009. Potato: A History of the Propitious Esculent. Yale University Press, New Haven, CT, U. S.A.

Rietman, H. 2011. Putting the Phytophthora infestans genome sequence at work: Multiple novel avirulence and potato resistance gene candidates revealed. Ph.D. thesis. Waneningen University, The Netherlands.

Rouppe van der Voort, J., Kanyuka, K., van der Vossen, E., Bendahmane, A., Mooijman, P., Klein-Lankhorst, R., Stiekema, W., Baulcombe, D. and Bakker, J. 1999. Tight physical linkage of the nematode resistance gene $\mathrm{Gpa} 2$ and the virus resistance gene $\mathrm{Rx}$ on a single segment introgressed from the wild species Solanum tuberosum subsp. andigena CPC 1673 into cultivated potato. Mol. Plant-Microbe Interact. 12:197206.

Simons, G., Groenendijk, J., Wijbrandi, J. Reijans, M., Groenen, J., Diergaarde, P., Van der Lee, T., Bleeker, M., Onstenk, J., Both, M., Haring, M., Mes, J., Cornelissen, B., Zabeau, M., and Vos, P. 1998. Dissection of the Fusarium I-2 gene cluster in tomato reveals six homologs and one active gene copy. Plant Cell 10:1055-1068.

Sliwka, J., Jakuczun, H., Kamiński, P., and Zimnoch-Guzowska, E. 2010. Marker-assisted selection of diploid and tetraploid potatoes carrying Rpi-phul, a major gene for resistance to Phytophthora infestans. J. Appl. Genet. 51:133-140.

Song, J., Bradeen, J. M., Naess, S. K. Raasch, J. A., Wielgus, S. M., Haberlach, G. T., Liu, J., Kuang, H., Austin-Phillips, S., Buell, C. R., Helgeson, J. P., and Jiang, J. 2003. Gene RB cloned from Solanum bulbocastanum confers broad spectrum resistance to potato late blight. Proc. Natl. Acad. Sci. U.S.A. 100:9128-9133.

Stewart, H. E., Bradshaw, J. E., and Pande, B. 2003. The effect of the presence of $R$-genes for resistance to late blight (Phytophthora infestans) of potato (Solanum tuberosum) on the underlying level of field resistance. Plant Pathol. 52:193-198.

Takken, F. L., Thomas, C. M., Joosten, M. H., Golstein, C., Westerink, N. Hille, J., Nijkamp, H. J., De Wit, P. J., and Jones, J. D. 1999. A second gene at the tomato $c f-4$ locus confers resistance to Cladosporium fulvum through recognition of a novel avirulence determinant. Plant $\mathrm{J}$. 20:279-288.

Tan, M. Y., Hutten, R. C., Visser, R. G., and van Eck, H. J. 2010. The 
effect of pyramiding Phytophthora infestans resistance genes RPi-mcdl and $R P i$-ber in potato. Theor. Appl. Genet. 121:117-125.

Thompson, J. D., Gibson, T. J., Plewniak, F., Jeanmougin, F., and Higgins, D. G. 1997. The ClustalX windows interface: Flexible strategies for multiple sequence alignment aided by quality analysis tools. Nucleic Acids Res. 25:4876-4882.

van der Hoorn, R. A., Laurent, F., Roth, R., and De Wit, P. J. 2000 Agroinfiltration is a versatile tool that facilitates comparative analyse of Avr9/Cf-9-induced and Avr4/Cf-4-induced necrosis. Mol. Plant-Microbe Interact. 13:439-446.

van der Vossen, E., Sikkema, A., Hekkert, B. T. L., Gros, J., Stevens, P., Muskens, M., Wouters, D., Pereira, A., Stiekema, W., and Allefs, S. 2003. An ancient $R$ gene from the wild potato species Solanum bulbocastanum confers broad-spectrum resistance to Phytophthora infestans in cultivated potato and tomato. Plant J. 36:867-882.

van der Vossen, E. A., Gros, J., Sikkema, A., Muskens, M., Wouters, D., Wolters, P., Pereira, A., and Allefs, S. 2005. The Rpi-blb2 gene from Solanum bulbocastanum is a $\mathrm{Mi}-1$ gene homolog conferring broadspectrum late blight resistance in potato. Plant J. 44:208-222.

van Engelen, F. A., Molthoff, J. W., Conner, A. J., Nap, J. P., Pereira, A., and Stiekema, W. J. 1995. pBINPLUS: An improved plant transformation vector based on pBIN19. Trans. Res. 4:288-290.

van Os, H., Andrzejewski, S., Bakker, E., Barrena, I., Bryan, G. J., Caromel,
B., Ghareeb, B., Isidore, E., de Jong, W., van Koert, P., Lefebvre, V. Milbourne, D., Ritter, E., Rouppe van der Voort, J. N. A. M., RousselleBourgeois, F., van Vliet, J., Waugh, R., Visser, R. G. F., Bakker, J. and van Eck, H. J. 2006. Construction of a 10,000 marker ultra-dense genetic recombination map of potato: Providing a framework for accelerated gene isolation and a genome-wide physical map. Genetics 173:1075-1089.

Visser, R. G., Somhorst, I., Kuipers, G. J., Ruys, N. J., Feenstra, W. J., and Jacobsen, E. 1991. Inhibition of the expression of the gene for granulebound starch synthase in potato by antisense constructs. Mol. Gen. Genet. 225:289-296.

Vleeshouwers, V. G., Rietman, H., Krenek, P., Champouret, N., Young, C., Oh, S. K., Wang, M., Bouwmeester, K., Vosman, B., Visser, R. G., Jacobsen, E., Govers, F., Kamoun, S., and van der Vossen, E. 2008. Effector genomics accelerates discovery and functional profiling of potato disease resistance and Phytophthora infestans avirulence genes. PLOS One 8:e2875. Published online.

Zhu, S. X., Nijenhuis, M., Bergervoet-van Deelen, J. E. M., Vossen, J. H., Visser, R. G. F., and Jacobsen, E. 2010. Triple $R$-gene stacking for sustainable resistance to late blight in potato. Page 79 in: Abstract Book of the European Association for Potato Research EUCARPIA Congress "Potato Breeding After Completion of the DNA Sequence of the Potato Genome", 27-30 June, 2010, Wageningen, The Netherlands. Published online.

The citation for Rietman 2011 has been added to the online version on September 16, 2011. 